\title{
Procalcitonin and C-reactive Protein Measurements in the Early Diagnosis of Surgical Site Infections After Cesarean Section
}

\section{Sezaryen Sonrası Cerrahi Alan Enfeksiyonlarının Erken Dönem Tanısında Prokalsitonin ve C-reaktif protein Ölçümlerinin Yeri}

\author{
Derya Kanza Gül $1^{*}$ \\ ${ }^{1}$ Medipol University School of Medicine Health, Department of Gynecology and Obstetrics, Istanbul, Turkey. \\ e-mail: deryakanza@yahoo.com \\ ORCID: 0000-0001-8879-9299 \\ *Sorumlu yazar/ Corresponding Author: Derya Kanza Gül \\ Gönderim Tarihi / Received: 12.09.2020 \\ Kabul Tarihi / Accepted: 14.12.2020 \\ DOI: $10.34087 /$ cbusbed. 794037
}

\begin{abstract}
Giriş ve Amaç: Sezaryen sonrası ölçülen serum prokalsitonin (PKT) düzeylerinin cerrahi alan enfeksiyonu (CAE)'ların erken tanısında diğer enfeksiyon belirteçlerine gore üstün olup olmadığını belirlemeyi amaçladık.

Gereç ve Yöntemler: Bu çalışma, Kasım 2018 ile Nisan 2019 tarihleri arasında Özel Hastane kadın doğum kliniğimizde elektif primer sezaryen ile doğum yapan 249 hasta üzerinde gerçekleştirildi. Postoperatif 6., 12 . ve 24. saatlerde serum PKT, C-reaktif protein (CRP) ve beyaz kan hücresi sayılarının ölçümleri yapıldı. Hastalar postoperatif 2., 4. ve 7. günlerde CAE açısından incelendi.

Bulgular: Katılımcıların 15'inde (\%6) cerrahi alan enfeksiyonu gelişti. PKT, CAE'ların en hassas ve spesifik belirleyicisiydi. PKT için CAE'nın öngörülmesinde eğri altındaki alan 0.912 (\% 95 CI: 0,79-1) ve kesme noktası 0,099 $\mathrm{ng} / \mathrm{ml}, \%$ 93,3 duyarlılık ve \% 92,3 özgüllük idi ( $\mathrm{p}<0.001)$. CAE tahmininde CRP eğri altındaki alan (EAA) 0.854 (\% 95 CI: 0.782 - 0.926) ve kesme noktas1 $16.95 \mathrm{mg} / \mathrm{dL}, \% 80$ hassasiyet ve \% 82,4 özgüllük idi. CAE'yi öngörmede beyaz kan hücresi için eğri altındaki alan (AUC) 0.819 (\% 95 CI: 0.708-0.931) ve kesme noktasi 18.8x109/L, \% 73,3 hassasiyet ve \% 83,0 özgüllük idi.

Sonuç: Serum PKT düzeyleri, sezaryen sonrası CAE'ların erken tanısında diğer konvansiyonel enfeksiyon belirteçlerinden daha duyarlı ve özgün bir belirteç olarak bulundu.
\end{abstract}

Anahtar kelimeler: Cerrahi alan enfeksiyonu, C-reaktif protein, Prokalsitonin, Sezaryen.

\begin{abstract}
Objective: We aimed to determine whether serum procalcitonin (PCT) levels measured after cesarean section were superior to the levels of other infection markers in the early diagnosis of surgical site infection (SSI).

Materials and Methods: The present study was conducted with consecutive 249 patients who underwent elective primary cesarean delivery in our obstetrics clinic of a Private Hospital between November 2018 and April 2019. Measurements of serum PCT, C-reactive protein (CRP) and white blood cell (WBC) counts were performed at the postoperative $6^{\text {th }}, 12^{\text {th }}$ and $24^{\text {th }}$ hours. The participating patients were examined for SSI on the postoperative $2^{\text {nd }}, 4^{\mathrm{h}}$ and $7^{\text {th }}$ days.

Results: Of the participants, $15(6 \%)$ developed surgical site infections, PCT was the most sensitive and specific marker of the SSI. Area under the curve (AUC) for PCT in predicting the SSI was 0.912 (95\% CI: 0.79-1) and cutoff point was $0.099 \mathrm{ng} / \mathrm{ml}$ with a sensitivity of $93.3 \%$, and specificity of $92.3 \%(\mathrm{p}<0.001)$. Area under the curve (AUC) for CRP in predicting the SSI was 0.854 (95\% CI: 0.782 - 0.926) and cutoff point was $16.95 \mathrm{mg} / \mathrm{dL}$ with a sensitivity of $80 \%$, and specificity of $82.4 \%$. Area under the curve (AUC) for WBC in predicting the SSI was 0.819 (95\% CI: $0.708-0.931$ ) and cutoff point was $18.8 \times 10^{9} / \mathrm{L}$ with a sensitivity of $73.3 \%$, and specificity of $83.0 \%$.

Conclusion: Serum PCT levels were found to be a more sensitive and specific marker in the early diagnosis of SSI after cesarean section than were the other conventional infection markers.
\end{abstract}

Keywords: Cesarean section, C-reactive protein, Procalcitonin, Surgical site infection. 


\section{Introduction}

One of the most common surgical procedures in the world is cesarean [1,2]. Surgical site infections (SSI) are one of the most common complications after cesarean section and its prevalence varies between $3 \%$ and $15 \%$ from one country to another [3,4]. According to the Center for Disease Control and Prevention (CDC), SSI is a condition where there is at least one criterion from purulent drainage, redness and / or swelling of the incision, and wound separation. Long-term stays in the hospital lead to both mother-baby separation, leading to emotional trauma, and economic losses [5]. Therefore, the leading target in SSI should be early diagnosis and treatment [4].

Although biochemical markers such as $\mathrm{C}$ reactive protein (CRP) and white blood cell (WBC) which have been used for a long time are preferred to detect postoperative surgical site infections, they are not always sufficient to distinguish between the infection and inflammation of the surgical site. Therefore, physicians have been using other possible markers in the last 10 years. The most popular of these markers is procalcitonin (PCT).

Procalcitonin (PCT) is the pro-peptide of calcitonin, which is normally secreted by the thyroid C cells. PCT is a 116-amino acid, and biochemically similar to its predecessor calcitonin (CT) [6]. However, it lacks hormonal activity. Its half-life in healthy individuals ranges from 25 to 30 hours. In normal physiological conditions, the blood PCT level is between $0.01 \mathrm{ng} / \mathrm{mL}$ and $0.04 \mathrm{ng} / \mathrm{mL}[7,8]$. In many studies, the upper value of PCT is accepted as $0.05 \mathrm{ng} / \mathrm{ml}$ [9]. That procalcitonin is the response of the human body to a bacterial infection was first discovered by Dandona et al. in 1990 [10]. A high level of PCT in the blood indicates not only severe bacterial infection and sepsis $[11,12,13,14]$, but also postoperative complications $[15,16,17,18]$.

To date, there are very few studies on the role of PCT in early detection of surgical site infections after cesarean section [19]. Thus, we aimed to determine whether PCT levels measured at after cesarean were superior to other infection markers such as CRP and WBC in the early detection of postoperative surgical site infections, and to detect the biochemical changes in the blood of patients with and without postoperative surgical site infections.

\section{Materials and Methods}

The study was approved by the ethical committee of Medipol University noninvasive clinical research (Reference number: 108400098-604.01.01-E.47627 Date:2018/10/30). Institution permission was obtained before the study started. Informed consent form was taken from all participants. All the procedures were performed in accordance with rules regarding studies involving human participants by taking into account the ethical standards of the institutional and/or national research committee and the 1964 Helsinki declaration and its later amendments or comparable ethical standards. Nine hundred pregnant women presented to the obstetrics outpatient clinics of a Private Nisa Hospital between November 2018 and April 2019. Of them, 420 presented to have an elective cesarean delivery. 249 consecutive primipar pregnant women in accordance with the inclusion criteria were included in the study.

The inclusion criteria were being between the ages of 20 40 , having a singleton pregnancy, fiirst pregnancy and having given birth with elective cesarean surgery. The exclusion criteria were history of chorioamnionitis and early membrane rupture, start of labor pains, presence of preoperative infection, elevated pre-operative WBC and CRP values, diseases with an immune deficiency syndrome predisposing to infection, deep infections, Infectious conditions, such as endometritis, urinary tract infections, endometritis other than SSI.

All the patients were administered adequate general and spinal anesthesia and then they were catheterized with Foley's catheter under aseptic conditions. After catheterization, all the vaginal walls and fornices of the participants in patients were cleaned with sterile square gauze impregnated with three units of povidone iodine solution respectively. The cleaning agents were applied to 360 degrees of the vaginal walls and fornices by the surgical doctor for $30 \mathrm{sec}$. Skin cleansing of all the patients was performed with an abdominal scrub. All patients were given $2 \mathrm{~g}$ of cefazolin sodium for prophylaxis after removal of the placenta. All patients had the same standard preoperative preparation and were operated by the same surgical team. Postoperative routine care was applied to all patients.

All patients were examined in terms of maternal age, weight, height, socio-demographic characteristics, operation duration time, length of hospital stay, postoperative 24th hour fever, surgical site pain VAS score, preoperative hemoglobin and WBC count. Blood samples were taken from all participants at the 6th, 12th and 24th hours to evaluate PCT, CRP and WBC levels. The patients were monitored for infection in the postoperative period using clinical. Blood, urine, and sputum cultures were taken from clinically suspected patients. An occlusive dressing placed on the surgical site postoperatively was removed on the $2^{\text {nd }}, 4^{\text {th }}$ and $7^{\text {th }}$ days to inspect the wound in all patients.

Surgical site infection is defined as erythema or wound edge separation with purulent discharge containing cesarean incision site. Clinical findings were evaluated together with inflammatory laboratory findings, culture taken from the wound. Empirical antibiotic therapy (second generation cephalosporin) was started when SSI was suspected. According to the Centers for Disease Control and Prevention (CDC), patients who developed SSI were hospitalized.

Serum PCT levels were measured with an immunoluminometric PCT kit (Germany) and recorded in $\mathrm{ng} / \mathrm{ml}$. Serum CRP levels were measured using a C501 module (Switzerland) and recorded in $\mathrm{mg} / \mathrm{dL}$. Visual Analog Scale (VAS): It was developed by Bond and Pilowsky in 1966 for the first time [20]. VAS is a 10 cm scale, defined as "painless" on one end and "worst pain" on the other. VAS assessment is defined as no pain: $0 \mathrm{~cm}$, Slight pain: $0.5 \mathrm{~cm}-3.0 \mathrm{~cm}$, Moderate pain: $3.5 \mathrm{~cm}$ - $6.5 \mathrm{~cm}$ and Severe pain: $7.0 \mathrm{~cm}-10.0 \mathrm{~cm}$ 
The primary outcome of the study was determine whether PCT levels measured at after cesarean were superior to other infection markers such as CRP and WBC in the early detection of postoperative surgical site infections 2.1.Statistical Analysis

The data were analyzed using the IBM SPSS V23. Whether the data were normally distributed was tested with Kolmogorov Smirnov and Shapiro Wilk tests. For the comparison of the non-normally distributed data for surgical site infections, Mann Whitney U test was used. All the categorical data were compared with the chisquare test. ROC analysis was used to determine whether PCT and CRP values are good predictors of wound formation. P-values of $<0.05$ were considered statistically significant. The results of the multivariate analysis were calculated as odds ratio and $95 \%$ confidence interval. Receiver operating characteristic (ROC) curves and there spective areas under the curve
(AUC) were calculated to evaluate the predictive value of each marker and to determine the cutoff level for SSI prediction of each marker.

\section{Results and Discussion}

The study sample included 260 patients. Of them, 11 were identified to have infections other than surgical site infections in the postoperative period and were excluded from the study. Of them, 5 had urinary tract infections, 4 had lower respiratory tract infections and 2 had upper respiratory tract infections. Of the participants, $15(6 \%)$ developed surgical site infections, $10(4 \%)$ developed superficial surgical site infections and were successfully treated with oral and intravenous antibiotics. Five (2\%) of the participants had deep wound infection, and 2 of them received long-term intravenous antibiotic therapy following tissue debridement.

Table 1. Relationship between the participants' demographic characteristics and development of surgical site infection

\begin{tabular}{|c|c|c|c|c|}
\hline & \multicolumn{4}{|c|}{ Surgical site infection * } \\
\hline & $\begin{array}{l}\text { Yes } \\
(n=15)\end{array}$ & $\begin{array}{l}\text { No } \\
(\mathrm{n}=234)\end{array}$ & $\begin{array}{l}\text { Total } \\
(\mathrm{n}=249)\end{array}$ & \multirow[t]{2}{*}{$\mathbf{p}$} \\
\hline & $\mathrm{n} \%$ & $\mathrm{n} \quad \%$ & $\mathrm{n} \quad \%$ & \\
\hline \multicolumn{5}{|l|}{ Marital status } \\
\hline Married & $15(6)$ & $234(94)$ & $249(100)$ & --- \\
\hline \multicolumn{5}{|l|}{ Length of marriage } \\
\hline $1-5$ years & $8(7)$ & $106(93)$ & $114(45.8)$ & \multirow{3}{*}{0.736} \\
\hline $6-10$ years & $7(5.4)$ & $123(94.6)$ & $130(52.2)$ & \\
\hline$\geq 11$ years & $0(0)$ & $5(100)$ & $5 \quad$ (2) & \\
\hline \multicolumn{5}{|l|}{ Educational attainment } \\
\hline Illiterate & 0 & $4 \quad(100)$ & $4 \quad(1.6)$ & \multirow{4}{*}{0.859} \\
\hline Primary school graduate & $6(7.7)$ & $72(92.3)$ & $78 \quad(31.3)$ & \\
\hline High school graduate & $7(5.4)$ & 123 (94.6) & $130(52.2)$ & \\
\hline University graduate & $2(5.4)$ & 35 (94.6) & 37 (14.9) & \\
\hline \multicolumn{5}{|l|}{ Income-generating jobs } \\
\hline Yes & $5(5.2)$ & $92(94.8)$ & $97(39)$ & \multirow{2}{*}{0.645} \\
\hline No & $10(6.6)$ & $142(93.4)$ & $152(61)$ & \\
\hline \multicolumn{5}{|l|}{ Income status } \\
\hline Income less than expenses & $2(5.4)$ & 35 (94.6) & $37(14.9)$ & \multirow{3}{*}{0.775} \\
\hline Income equal to expenses & $13(6.3)$ & $192(93.7)$ & $205(82.3)$ & \\
\hline Income more than expenses & $0(0)$ & $7(100)$ & $7(2.8)$ & \\
\hline \multicolumn{5}{|l|}{ Social security } \\
\hline Yes & $15(6.1)$ & $231(93.9)$ & $246(98.8)$ & \multirow{2}{*}{0.659} \\
\hline No & $0(0)$ & $3(100)$ & $3(1,2)$ & \\
\hline \multicolumn{5}{|l|}{ Family type } \\
\hline Nuclear & $15(6.4)$ & 219 (93.6) & 234 (94) & \\
\hline Extended & $0(0)$ & 15 (100) & $15(6)$ & 0.312 \\
\hline
\end{tabular}

$\chi^{2}$ : Pearson Chi-square test 
Investigation of the relationship between the participants demographic characteristics and development of surgical site infection revealed there were no statistically significant relationship between development of surgical site infections and demographic characteristics such as the length of marriage, educational status, working at an income-generating jobs, having social security, and family type (Table 1).

There was no statistically significant correlation between the median values for age, height, weight, preoperative

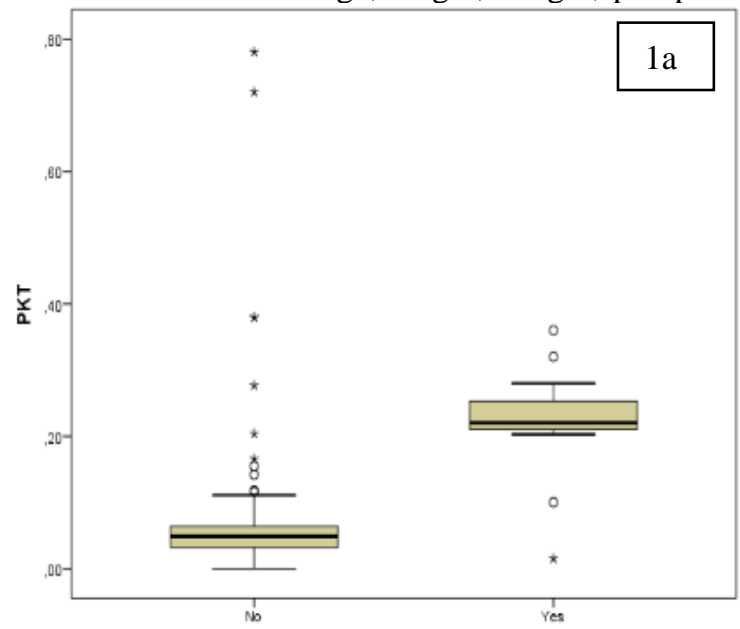

hemoglobin level $(\mathrm{Hb})$, preoperative leukocyte level (WBC) postoperative hemoglobin level $(\mathrm{Hb})$ and the presence of surgical site infections. However, the median values for the postoperative pain of surgical site VAS scores, fever, length of hospital stay, duration of surgery, $(\mathrm{p}<0.001)$ the postoperative 6th hour WBC, CRP and PCT levels and the postoperative 12th and 24th hour CRP and PCT levels differed statistically significantly in terms of the presence of a surgical site infection (Table 2, Figure 1)

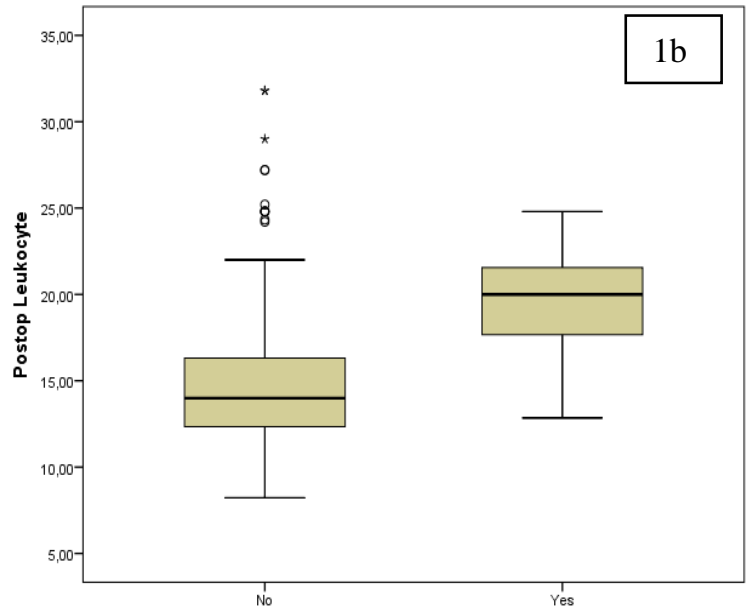

Figure 1a,1b. Baseline postoperative PCT, CRP concentrations, postoperative WBC count in the study groups

To calculate the cutoff points for each parameter in predicting SSI, the area under the curve (AUC) and Youden's index were used. According to the comparison of the postoperative 6th hour PCT, CRP and WBC values revealed that when the cutoff point for PCT was $0.099 \mathrm{ng} / \mathrm{mL}$, the area under the curve (AUC) was calculated as 0.912 . At this stability, the sensitivity was 93.3\%, specificity was $92.3 \%$ and accuracy was $92.4 \%$. When the cutoff point was $16.95 \mathrm{mg} / \mathrm{dL}$ for the postoperative 6th hour CRP, the area under the curve (AUC) was calculated as 0.854 . At this stability, the sensitivity was $80 \%$, specificity was $82.5 \%$ and accuracy was $82.3 \%$ (Table 3 and Figure 2). When the cutoff point was $18.8 \times 109 / \mathrm{L}$ for the postoperative 6th hour WBC count, the area under the curve (AUC) was calculated as 0.819 . At this stability, the sensitivity was $73.33 \%$, specificity was $88.03 \%$ and accuracy was $87.15 \%$ (Table 3 and Figure 2).

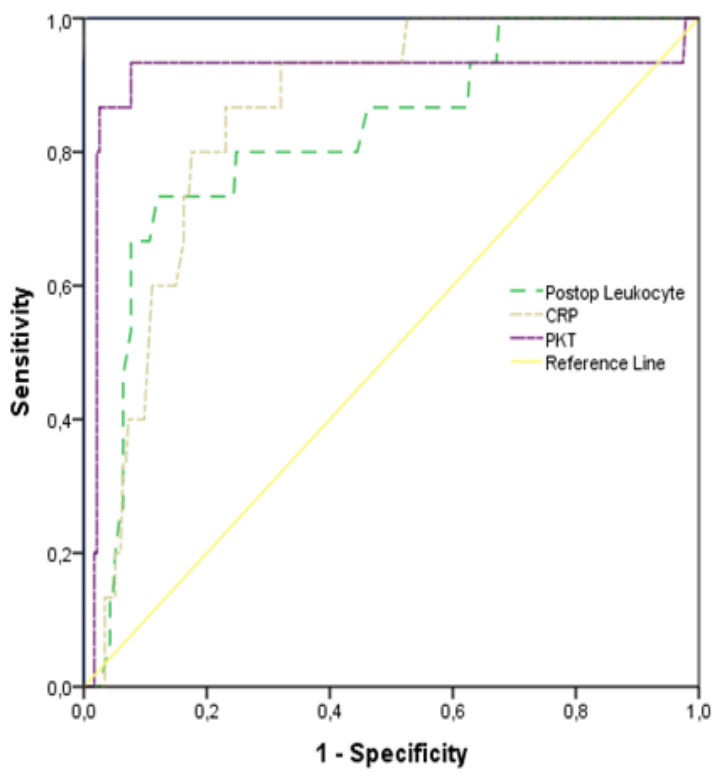

Figure 2. ROC analysis for PCT, CRP levels and Leukocyte (WBC) count at the postoperative $6^{\text {th }}$ hour 
Table 2.Comparison of parameters in terms of the presence of surgical site infection

\begin{tabular}{|c|c|c|c|c|}
\hline & \multicolumn{3}{|c|}{ Presence of Surgical Site Infections* } & \multirow{3}{*}{$\mathrm{p}$} \\
\hline & Yes $(n=15)$ & No $(n=234)$ & Total $(n=249)$ & \\
\hline & Median (min-max) & Median (min-max) & Median (min-max) & \\
\hline Age (year) & $30(21-34)$ & $29(21-40)$ & $29(21-40)$ & 0.534 \\
\hline Height $(\mathrm{cm})$ & $160(150-170)$ & $160(150-174)$ & $160(150-174)$ & 0.455 \\
\hline Weight (kg) & $65(50-80)$ & $68(48-109)$ & $68(48-109)$ & 0.243 \\
\hline \multicolumn{5}{|c|}{ Postoperative $24^{\text {th }}$ fever } \\
\hline${ }^{\circ} \mathrm{C}$ & $37.2(36.2-38)$ & $36.3(35.5-37.8)$ & $36.4(35.5-38)$ & $<0.001$ \\
\hline \multicolumn{5}{|c|}{ Postoperative $24^{\text {th }}$ surgical } \\
\hline site pain VAS score & $7(6-9)$ & $4(2-7)$ & $4(2-9)$ & $<0.001$ \\
\hline \multicolumn{5}{|l|}{ Length of hospital stay } \\
\hline (hour) & $50(32-60)$ & $35(30-48)$ & $36(30-60)$ & $<0.001$ \\
\hline \multicolumn{5}{|l|}{ Duration of surgery } \\
\hline (minute) & $30(25-45)$ & $30(23-40)$ & $30(23-45)$ & $<0.001$ \\
\hline Preoperative $\mathrm{Hb} \mathrm{g} / \mathrm{dL}$ & $12.3(10.2-14.7)$ & $12.3(8.4-14.5)$ & $12.3(8.4-14.7)$ & 0.646 \\
\hline \multicolumn{5}{|l|}{ Preoperative WBC(x } \\
\hline $\left.10^{9} / \mathrm{L}\right)$ & $11.7(9-20)$ & $10.7(4-18)$ & $10.7(4-20)$ & 0.034 \\
\hline \multicolumn{5}{|c|}{ Postoperative $6^{\text {th }}$ hour $\mathrm{Hb}$} \\
\hline $\mathrm{g} / \mathrm{dL}$ & $11.4(8.9-12.7)$ & $11.2(7.4-14.3)$ & $11.2(7.4-14.3)$ & 0.439 \\
\hline \multicolumn{5}{|l|}{ Postoperative $6^{\text {th }}$} \\
\hline hourWBC(x 109/L) & $20(12.9-24.8)$ & $14(8.2-31.8)$ & $14(8.2-31.8)$ & $<0.001$ \\
\hline \multicolumn{5}{|l|}{ Postoperative $6^{\text {th }}$ hour } \\
\hline CRP mg/dL & $25(7.9-49)$ & $8.3(0.9-85.6)$ & $9.3(0.9-85.6)$ & $<0.001$ \\
\hline \multicolumn{5}{|l|}{ Postoperative $6^{\text {th }}$ hour } \\
\hline PCT ng/mL & $0.2(0-0.4)$ & $0(0-0.8)$ & $0.1(0-0.8)$ & $<0.001$ \\
\hline \multicolumn{5}{|l|}{ Postoperative $12^{\text {th }}$ hour } \\
\hline CRP mg/dL & $50(21-110)$ & $23.3(3.5-106)$ & $24.5(3.5-110)$ & $<0.001$ \\
\hline \multicolumn{5}{|l|}{ Postoperative $12^{\text {th }}$ hour } \\
\hline PCT ng/mL & $0.28(0.12-0.4)$ & $0.07(0.01-20.8)$ & $0.07(0.01-20.8)$ & $<0.001$ \\
\hline \multicolumn{5}{|l|}{ Postoperative $24^{\text {th }}$ hour } \\
\hline $\mathrm{CRP} \mathrm{mg} / \mathrm{dL}$ & $88(50-130)$ & $59.1(3.5-185)$ & $60.7(3.5-185)$ & $<0.001$ \\
\hline \multicolumn{5}{|l|}{ Postoperative } \\
\hline \multicolumn{5}{|l|}{$24^{\text {th }}$ hour PCT } \\
\hline $\mathrm{ng} / \mathrm{mL}$ & $0.32(0.12-0.45)$ & $0.07(0.02-4.66)$ & $0.08(0.02-4.66)$ & $<0.001$ \\
\hline
\end{tabular}


Table 3. Results of ROC analysis for postoperative PCT, CRP and WBC levels at the postoperative $6^{\text {th }}$ hour

\begin{tabular}{llll}
\hline & PCT & CRP & WBC \\
\hline Cutoff point & $0.099 \mathrm{ng} / \mathrm{mL}$ & $16.95 \mathrm{mg} / \mathrm{Dl}$ & $18.8 \times 10^{9} / \mathrm{L}$ \\
AUC $(\% 95 \mathrm{CI})$ & $0.912(0.79-1)$ & $0.854(0.782-0.926)$ & $0.819(0.708-0.931)$ \\
Sensitivity & $93.33(68.04-99.83)$ & $80(51.91-95.67)$ & $73.33(44.90-92.21)$ \\
Specificity & $92.31(88.12-95.38)$ & $82.48(76.99-87.12)$ & $88.03(83.17-91.90)$ \\
Positive Predictive Value & $43.75(32.84-55.30)$ & $22.64(16.73-29.89)$ & $28.21(19.83-38.42)$ \\
Negative Predictive Value & $99.54(97.02-99.93)$ & $98.47(95.89-99.44)$ & $98.10(95.69-99.17)$ \\
Accuracy & $92.37(88.34-95.34)$ & $82.33(77.01-86.86)$ & $87.15(82.34-91.04)$ \\
\hline
\end{tabular}

AUC: Area under curve, CRP:C-reactive protein, PCT:Procalcitonin, WBC:white blood cell,

Efficacy of PCT and CRP values measured at the postoperative $6^{\text {th }}, 12^{\text {th }}$ and $24^{\text {th }}$ hours in predicting SSI:

When the cutoff point was $18.8 \mathrm{ng} / \mathrm{mL}$ for the postoperative $6^{\text {th }}$ hour PCT, the area under the curve (AUC) was calculated as 0.912. At this stability, the sensitivity was $93.3 \%$, specificity was $92.3 \%$ and accuracy was $92.4 \%$.

When the cutoff point was $0.1495 \mathrm{ng} / \mathrm{mL}$ for the postoperative $12^{\text {th }}$ hour PCT, the area under the curve (AUC) was calculated as 0.964 . At this stability, the sensitivity was $93.3 \%$, specificity was $91.5 \%$ and accuracy was $91.6 \%$.

When the cutoff point was $0.2025 \mathrm{ng} / \mathrm{mL}$ for the postoperative $24^{\text {th }}$ hour PCT, the area under the curve
(AUC) was calculated as 0.971. At this stability, the sensitivity was $93.3 \%$, specificity was $97 \%$ and accuracy was $96.8 \%$ (Table 4, Figure 3)

When the cutoff point was 16.95 for the postoperative $6^{\text {th }}$ hour CRP, the area under the curve (AUC) was calculated as 0.854 . At this stability, the sensitivity was $80 \%$, specificity was $82.5 \%$ and accuracy was $82.3 \%$

When the cutoff point was $34.95 \mathrm{mg} / \mathrm{dL}$ for the postoperative $12^{\text {th }}$ hour CRP, the area under the curve (AUC) was calculated as 0.866 . At this stability, the sensitivity was $86.7 \%$, specificity was $81.2 \%$ and accuracy was $81.5 \%$.

Table 4. Results of ROC analysis for PCT levels at the postoperative $6^{\text {th }}, 12^{\text {th }}$ and $24^{\text {th }}$ hours

\begin{tabular}{llll}
\hline & $\mathbf{6}^{\text {th }}$ hour PCT & $\mathbf{1 2}^{\text {th }}$ hour PCT & $\mathbf{2 4}^{\text {th }} \mathbf{h o u r}$ PCT \\
\hline Cutoff point ng/mL & 0.099 & 0.1495 & 0.2025 \\
AUC (\%95CI) & $0.912(0.790-1.000)$ & $0.964(0.938-0.989)$ & $0.971(0.945-0.998)$ \\
Sensitivity & $0.933(0.681-0.998)$ & $0.933(0.681-0.998)$ & $0.933(0.681-0.998)$ \\
Specificity & $0.923(0.881-0.954)$ & $0.915(0.871-0.947)$ & $0.970(0.939-0.988)$ \\
PPV & $0.438(0.328-0.553)$ & $0.412(0.311-0.521)$ & $0.667(0.488-0.808)$ \\
NPV & $0.995(0.970-0.999)$ & $0.995(0.967-0.993)$ & $0.996(0.972-0.999)$ \\
Accuracy & $0.924(0.883-0.953)$ & $0.916(0.874-0.947)$ & $0.968(0.938-0.986)$ \\
\hline AUC: Ara & & & \\
\hline
\end{tabular}

AUC: Area under curve, PCT:Procalcitonin, NPV: negative predictive value PPV:positive predictive value

When the cutoff point was $79.65 \mathrm{mg} / \mathrm{dL}$ for the postoperative $24^{\text {th }}$ hour CRP, the area under the curve (AUC) was calculated as 0.783 . At this stability, the sensitivity was $73.3 \%$, specificity was $72.7 \%$ and accuracy was $72.7 \%$ (Table 5, Figure 3). 

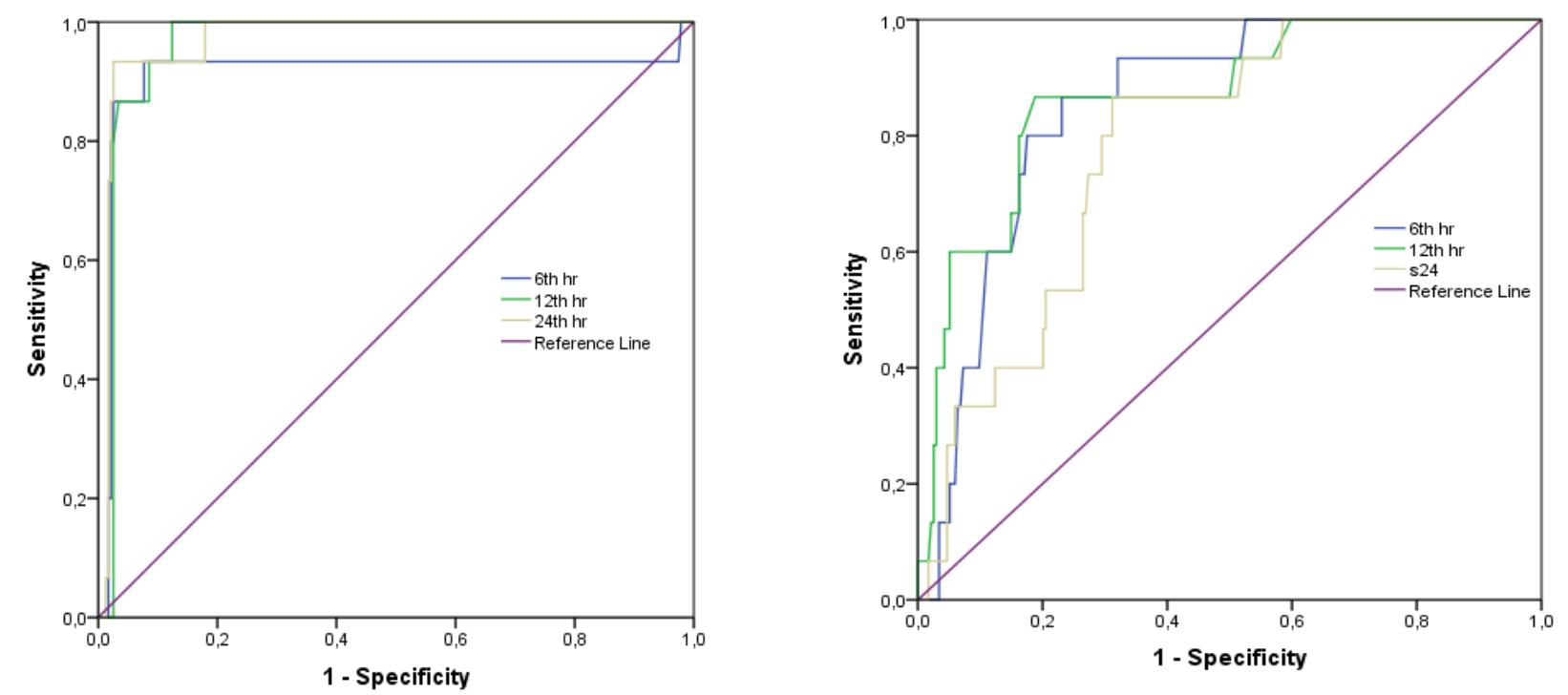

Figure 3. Receiver operating characteristic (ROC) curve of PCT and CRP for the prediction of SSI

Table 5. ROC analysis results for CRP levels at the postoperative $6^{\text {th }}, 12^{\text {th }}$ and $24^{\text {th }}$ hours

\begin{tabular}{llll}
\hline & $\mathbf{6}^{\text {th }}$ hour CRP & $\mathbf{1 2}^{\text {th }}$ hour CRP & $\mathbf{2 4}^{\text {th }}$ hour CRP \\
\hline Cutoff point mg/dL & 16.95 & 34.95 & 79.65 \\
AUC (\%95CI) & $0.854(0.782-0.926)$ & $0.866(0.775-0.956)$ & $0.783(0.692-0.874)$ \\
Sensitivity & $0.800(0.519-0.957)$ & $0.867(0.595-0.983)$ & $0.733(0.449-0.922)$ \\
Specificity & $0.825(0.770-0.871)$ & $0.812(0.756-0.860)$ & $0.727(0.665-0.783)$ \\
PPV & $0.226(0.167-0.298)$ & $0.228(0.175-0.292)$ & $0.147(0.106-0.199)$ \\
NPV & $0.985(0.959-0.994)$ & $0.989(0.963-0.997)$ & $0.977(0.948-0.990)$ \\
Accuracy & $0.823(0.770-0.869)$ & $0.815(0.761-0.862)$ & $0.727(0.667-0.781)$ \\
\hline
\end{tabular}

AUC: Area under curve, CRP:C-reactive protein, NPV: negative predictive value PPV:positive predictive value

\subsection{Discussion}

Of the participants, $15(6 \%)$ developed SSI, $10(4 \%)$ developed SSIs. $5(2 \%)$ of the participants had deep wound infection, and 2 of them received long-term intravenous antibiotic therapy following tissue debridement. The median values for the postoperative pain VAS scores, fever, length of hospital stay, duration of surgery, the postoperative 6th hour WBC count, CRP, and PCT levels and the postoperative 12th and 24th hour CRP and PCT levels were statistically significantly higher in the participants with a surgical site infection $(p<0.001)$. In their retrospective study conducted with patients having undergone posterior lumbar surgery in 3 centers between 2006 and 2016, Wang t et al. determined that Postoperative WBC count, CRP, PCT levels, duration of the surgery, blood loss and operation level, instrumentation surgery and incision length were statistically significantly higher in the patients who had surgical site infections [21].
In their study conducted with 98 intensive care patients with intracerebral hemorrhage, Kara et al. determined that the median (interquartile range) PCT levels were 4 $\mathrm{ng} / \mathrm{ml}(0.9-11)$ and $0.1 \mathrm{ng} / \mathrm{ml}(0.1-0.4)$ in patients who had infectious fever and central fever respectively, and there was a statistically significant difference between the groups $(\mathrm{p}<0.001)$. The areas under the curve (ROC) for predicting infectious or central fever PCT and CRP were calculated as $0.958 \mathrm{ng} / \mathrm{mL}(\mathrm{p}<0.001)$ and 0.816 $\mathrm{mg} / \mathrm{dL}(\mathrm{p}<0.001)$ respectively. There was a positive correlation between PCT and CRP levels in patients with infectious fever (rho: 0.461; $\mathrm{p}=0.003$ ), but this was not significant in patients with central fever [22].

High WBC count, a nonspecific inflammatory marker, is one of the SIRS criteria [23]. Although the WBC count and CRP level are more commonly used in screening of surgical site infection after cesarean section, PCT is a more sensitive and specific marker [18]. In the present study, according to the comparison of the postoperative 6th hour PCT, CRP and WBC values revealed that when 
the cutoff point for PCT was $0.099 \mathrm{ng} / \mathrm{mL}$, the area under the curve (AUC) was calculated as 0.912. At this stability, the sensitivity was $93.3 \%$, specificity was $92.3 \%$ and accuracy was $92.4 \%$. When the cutoff point was $16.95 \mathrm{mg} / \mathrm{dL}$ for the CRP, the area under the curve (AUC) was calculated as 0.854 . At this stability, the sensitivity was $80 \%$, specificity was $82.5 \%$ and accuracy was $82.3 \%$. When the cutoff point was $18.8 \times 109 / \mathrm{L}$ for the WBC, the area under the curve (AUC) was calculated as 0.819 . At this stability, the sensitivity was $73.33 \%$, specificity was $88.03 \%$ and accuracy was $87.15 \%$.

In the literature, a large number of publications in different surgical branches investigated the importance of PCT in detecting postsurgical site infections and emphasized its superiority over other infection markers. In their study conducted in 2018, Al-Jabiet al. found that PCT was a more sensitive and specific marker than CRP, WBC or ESR (Erythrocyte Sedimentation Rate) in predicting surgical site infections after spinal surgery [24]. In their study, the sensitivity and specificity values were $100 \%$ and $95.2 \%$ for PCT, $100 \%$ and $91.7 \%$ for CRP, $35.8 \%$ and $100 \%$ for $\mathrm{WBC}$, and $100 \%$ and $52.4 \%$ for ESR respectively. In the present study, when the cutoff point was $0.1495 \mathrm{ng} / \mathrm{ml}$ for PCT at the postoperative 12thhour, the sensitivity was $93.3 \%$ whereas the specificity was $91.5 \%$. When the cutoff point was $34.95 \mathrm{mg} / \mathrm{dl}$ for the postoperative 12 th hour CRP, the sensitivity and specificity were $86.7 \%$ and $81.2 \%$ respectively.

In a study conducted by Takakura et al. in 2013 with 114 patients, on the postoperative 1stand 3rddays, serum PCT levels and on the postoperative 3 rd day serum CRP levels were statistically significantly higher in patients having undergone colorectal surgery. At the postoperative 24thhour, cut off point for PCT was $0.77 \mathrm{ng} / \mathrm{mL}$ and the sensitivity was $83.3 \%$ and the specificity was $63.5 \%$ [25]. In the present study, when the cutoff point was 0.2025 $\mathrm{ng} / \mathrm{ml}$ for PCT at the postoperative 24th hour, the sensitivity and specificity were $93.3 \%$ and $97 \%$ respectively. When the cutoff point was $79.65 \mathrm{mg} / \mathrm{dL}$ for the postoperative 24 th hour CRP, the sensitivity and specificity were $73.3 \%$ and $72.7 \%$ respectively.

In the literature, the number of studies conducted on the role of postoperative procalcitonin level after cesarean section for the early detection of SSI is very limited, and these studies included small-size samples. In their study, Aslan Çetin et al. compared PCT and CRP levels in patients with post-cesarean surgical site infections, and consistent with the present study, they found that the PCT level was statistically significantly higher in patients with surgical site infections requiring secondary suture $(0.21$ vs. $0.05 \mathrm{ng} / \mathrm{ml}, \mathrm{p}<0.001)$. There was positive correlation between the serum PCT levels and the length of hospitalization $(\mathrm{p}<0.001)$. For the prediction of secondary suture need for PCT (AUC: 0.85) (95\% CI: $0.772-0.922$ ) and the cut-off point was $0.142 \mathrm{ng} / \mathrm{ml}$ with $75 \%$ precision and $97.8 \%$ specificity $(\mathrm{p}<0.001)$ [19].

If we compare the infection markers from an economic aspect, the cost of WBC, CRP and PCT tests in our hospital was $\$ 2, \$ 8$ and $\$ 20$ respectively. The present study indicated that PCT was superior to the other evaluated inflammatory markers in terms of sensitivity and specificity. Although procalcitonin is a more expensive marker, it contributes to the early diagnosis and treatment, reduces the length of hospital stay of the mother and her baby and thus can effectively reduce health care costs.

Increasing evidence suggests that PCT is an important marker in the diagnosis of postoperative infections and complications; therefore, further studies should be performed to compare the predictive value of PCT and other inflammatory parameters in the diagnosis of SSI.

The strength of our study is that in the literature, studies conducted on the role of PCT in the early detection of surgical site infections after cesarean section are very few. The limitation of our study is that we included primiparous women who underwent first cesarean section, our specific group may limit generalization.

\section{Conclusion}

In conclusion, in the present study, serum PCT levels measured at the postoperative 6th, 12th and 24th hours were determined to be a more sensitive and specific marker in the early diagnosis of SSI after cesarean section than were the other conventional infection markers such as CRP and WBC. Therefore, we recommend that after cesarean section, serum PCT levels should be routinely measured. We also recommend that to confirm and generalize our findings, future studies to be conducted on the issue should include larger samples.

\section{Acknowledgements and Disclosures}

The authors have no conflicts of interest to declare.

No funding received.

\section{Referanslar}

1. Niino, Y, The increasing cesarean rate globally and what we can do about it, BioScience Trends, 2011, 5(4), 139-150.

2.Souza, J.P, Betran, A.P, Dumont, A, De Mucio, B, GibbsPickens, C.M, Deneux-tharaux, C, et al., A global reference for caesareansectionrates (C-Model): a multicountry cross-sectional study, BJOG:An International Journal of Obstetrics \& Gynaecology,2016, 123(3), 427-36.

3.Zuarez-Easton, S, Zafran, N, Garmi, G, et al., Postcesarean wound infection: prevalence, impact, prevention, and management challenges, International Journal of Women's Health, 2017, 9, 8188 .

4. Olsen, M.A, Butler, A.M, Willers, D.M, et al., Attributable costs of surgical site infection and endometritis after low transverse cesarean delivery, Infection Control \& Hospital Epidemiology, 2010, 31(3), 276-282.

5. Salim, R, Braverman, M, Teitler, N, Berkovic, I, Suliman, A, Shalev, $\mathrm{E}$, Risk factors for infection following cesarean delivery: an interventional study, The Journal of Maternal-Fetal \& Neonatal Medicine, 2012, 25(12), 2708-2712.

6. Russwurm, S, Wiederhold, M, Oberhoffer, M, Stonans, I, Zipfel, PF, Reinhart, K, Molecular aspects and natural source of procalcitonin, Clinical Chemistry and Laboratory Medicine, 1999, 37(8), 789-797.

7.Nijsten, M, Olinga, P, The, T.H, de Vries, E.G, Koops, H.S, Groothuis, G.M, et al., Procalcitonin behaves as a fast responding acute phase protein in vivo and in vitro, Critical Care Medicine, 2000, 28(2), 458-461.

8. Giovanella, L, Serum procalcitonin and calcitonin normal values before and after calcium gluconate infusion, Experimental and Clinical Endocrinology \& Diabetes Reports, 2012, 120(3), 169-170. 
9. Wacker C, Prkno A, Brunkhorst FM, et al. Procalcitoninas a diagnostic marker for sepsis: a systematic review and meta-analysis. The Lancet Infectious Diseases, 2013, 13(5), 426-435.

10. Dandona, P, Nix, D, Wilson, M.F, Aljada, A, Love, J, Assicot, M, et al. Procalcitonin increase after endotoxin injection in normal subjects, The Journal of Clinical Endocrinology \& Metabolism 1994,79(6), 1605|-1608.

11. Recipon, G, Piver, E, Caille, A, et al., Is procalcitonin increased in cases of invasive amoebiasis? A retrospective, observational study, Diagnostic Microbiology and Infectious Disease, 2015, 83(4), 395399.

12. Chengfen, Y, Tong, L, Xinjing, G, Zhibo, L, Lei, X, Accuracy of procalcitonin for diagnosis of sepsis in adults: a Meta-analysis. Zhonghua Wei Zhong Bing Ji Jiu Yi Xue, 2015, 27(9), 743-749.

13. Linscheid, P, Seboek, D, Nylen, E.S, et al., In vitro and in vivo calcitonin I gene expression in parenchymal cells: a novel product of human adipose tissue, Endocrinology, 2003, 144(12), 5578-5584.

14. Potjo, M, Theron, A.J, Cockeran, R, Sipholi. N.N, Steel, H.C, Bale, T.V, Meyer, P.W.A, Anderson, R, Tintinger, G.R. Interleukin-10 and interleukin-1 receptor antagonist distinguish between patients with sepsis and the systemic inflammatory response syndrome (SIRS), Cytokine, 2019, 120, 227-233.

15. Caluianu EI et al., Utilizing Multiparameter Scores and Procalcitonin as Prognosis Markers for the Degree of Severity of Acute Pancreatitis, Current Health Sciences Journal, 2017, 43(4), 311-317.

16. Cossé, C, Sabbagh, C, Carroni, V, Galmiche, A, Rebibo, L, Regimbeau, J.M., Impact of a procalcitonin-based algorithm on the management of adhesion-related small bowel obstruction, Journal of Visceral Surgery, 2017, 154(4), 231-237.

17. Parli, S.E, Trivedi, G, Woodworth, A, Chang, P.K, Procalcitonin Usefulness in Acute Care Surgery and Trauma, Surgical Infection (Larchmt),. 2018, 19(2), 131-136.

18. Whicher, J, Bienvenu, J, Monneret, G, Procalcitonin as an acute phase marker, Annals of Clinical Biochemistry, 2001, 38(5), 483-493.

19. Cetin, B.A, Mathyk, B.A, Koroglu, N, et al., Serum procalcitonin levels in incisional surgical site infections requiring a secondary suture after cesarean sections, The Journal of Maternal-Fetal \& Neonatal Medicine, 2019, 32(24), 4108-4113.

20. Bond, M, Pilowsky, I. Subjective evaluation of its relationship with analgesic administration in pain and cancer patients. The Journal of Psychosomatic Research 1966, 10(2), 203-208.

21. Wang, T, Wang, H, Yang, D.L, Jiang, L.Q, Zhang, L.J, Ding, W.Y., Factors predicting surgical site infection after posterior lumbar surgery: A multicenter retrospective study, Medicine (Baltimore), 2017, 96(5), 6042.

22. Kara, S.S, Akbulut, A, Tartar, A.S, Akbulut, H.H, Demirdağ, K, Beştaş, A, Procalcitonin levels among patients with fever secondary to severe intracerebral infection, A cross-sectional study, Sao Paulo Medical Journal, 2019, 137(4), 349-355.

23. Oberhofer, D, Juras, J, Pavicic, A.M, et al., Comparison of Creactive protein and procalcitonin as predictors of postoperative infectious complications after elective colorectal surgery, Croatian Medical Journal, 2012, 53(6), 612-619.

24. Aljabi, Y, Manca, A, Ryan, J, Elshawarby, A, Value of procalcitonin as a marker of surgical site infection following spinal surgery, The Surgeon, 2019, 17(2), 97-101.

25. Takakura, Y, Hinoi, T, Egi, H, Shimomura, M, Adachi, T, et al., Procalcitonin as a predictive marker for surgical site infection in elective colorectal cancer surgery, Langenbecks Archives of Surgery, $2013,398(6), 833-839$.

http://edergi.cbu.edu.tr/ojs/index.php/cbusbed isimli yazarın CBU-SBED başlıklı eseri bu Creative Commons Alıntı-Gayriticari4.0 Uluslararası Lisansı ile lisanslanmıştır.

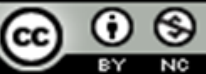

